\title{
KAJIAN EVALUASI KINERJA BANGUNAN TERHADAP SIAGA BENCANA GEMPA
}

\author{
Rofika Sinaga $^{1}$, Cindrawaty Lesmana ${ }^{2}$ \\ ${ }^{1}$ Alumni, Program Studi Teknik Sipil, Fakultas Teknik, Universitas Kristen Maranatha \\ ${ }^{2}$ Dosen Tetap, Program Studi Teknik Sipil, Fakultas Teknik, Universitas Kristen Maranatha \\ Jalan Prof. drg. Suria Sumantri, MPH. No. 65 Bandung 40164 \\ Email: cindrawaty.lesmana@eng.maranatha.edu
}

\begin{abstract}
ABSTRAK
Indonesia merupakan negara yang berada di wilayah rawan gempa karena letak geografisnya yang berada pada pertemuan tiga lempeng tektonik besar di dunia, yaitu lempeng Indo-Australia, lempeng Eurasia dan lempeng Pasifik. Kesiapsiagaan bangunan akan bahaya gempa sangat direkomendasikan untuk mengurangi risiko yang ditimbulkan oleh kejadian gempabumi yang tidak dapat diprediksi. Tujuan penulisan ini adalah mengevaluasi kesiapsiagaan bangunan pada salah satu Gedung Pendidikan di Bandung terhadap bencana gempa. Penilaian kesiapsiagaan bangunan dilakukan dengan cara observasi, wawancara, dan kuesioner untuk meninjau variabel pengetahuan, tindakan, dan varibel kesiapsiagaan.Penelitian menghasilkan bahwa kesiapsiagaan bangunan terhadap bencana gempa masih perlu ditingkatkan.
\end{abstract}

Kata kunci: kinerja bangunan, kesiap-siagaan, gempa..

\begin{abstract}
Being located on three active tectonic plates, Indo-Australian Plate, the Eurasian Plate and the Pacific Plate, Indonesia is a country that prone to Earthquakes. Therefore, Earthquake Preparedness is highly recommended strategy to better understand the risk and reduce the impact of an unpredictable earthquake.The purposes of this research were to assess the Earthquake Preparedness of Education Building in Bandung. The Earthquake Preparedness was evaluated through observation, questionnaires and interviews to assess three major variables: knowledge, action plans, and preparedness. The Earthquake preparedness is required many improvements.
\end{abstract}

Keywords: Performance-based evaluation, preparedness, earthquake.

\section{PENDAHULUAN}

Bencana alam selalu menarik lebihbanyakperhatian ketika sudah terjadi dan mengakibatkan banyak kerugian bagi manusia yang mengalaminya.Penanggulangan bencana dapat mengurangi resikokerugian akibatbencana dengan salah satunyamenerapkan siklus penanggulangan bencana (BNPB, 2011; UNESCO, 2015).Kesiapsiagaan merupakan salah satuelemen dalam siklus penanggulangan bencana, untuk jenis bencana apapun tanpa terkecuali jenis bencana gempa.Bangunan gedung siaga bencana gempa dibutuhkan seluruh kalangan pengguna bangunan gedung sesuai dengan manfaat bangunan gedung, karena dapat mengurangi risiko terjadinya bencana gempa (BNPB, 2011; UNESCO,2015).

Tujuan penelitian adalah mengevaluasi kesiapsiagaan bangunan geding pendidikan terhadap bencana gempa khususnya salah satu bangunan Gedung Pendidikan 
di Bandung.Batasan penelitian melingkupi penelitian pada salah satu bangunan Gedung Pendidikan di Bandung (Gedung Pendidikan Lama) dan siaga bencana terbatas hanya pada kesiapsiagaan terhadap bencana gempa.

\section{TINJAUAN PUSTAKA}

\subsection{Bencana}

Undang-undang Nomor 24 Tahun 2007 mengenai Penanggulangan Bencana menyebutkan definisi bencana adalah peristiwa atau rangkaian peristiwa yang mengancam dan mengganggu kehidupan dan penghidupan masyarakat yang disebabkan oleh faktor alam dan atau faktor non alam maupun faktor manusia, sehingga mengakibatkan timbulnya korban jiwa manusia, kerusakan lingkungan, kerugian harta benda, dan dampak psikologis. Bencana alam adalah bencana yang diakibatkan oleh peristiwa atau serangkaian peristiwa yang disebabkan oleh alam antara lain berupa gempa bumi, tsunami, gunung meletus, banjir, kekeringan, angin topan, dan tanah longsor (BNPB, 2015).

Kejadian bencana adalah peristiwa bencana yang terjadi dan dicatat berdasarkan tanggal kejadian, lokasi, jenis bencana, korban dan/ataupun kerusakan. Jika terjadi bencana pada tanggal yang sama dan melanda lebih dari satu wilayah, maka dihitung sebagai satu kejadian (BNPB, 2015).Beberapa jenis bencana alam adalah Gempa Bumi, Tsunami, Gunung Api, Banjir, Tanah Longsor, Kekeringan, Angin Topan, Kebakaran, Angin Puting Beliung, Gelombang Pasang, Abrasi, Wabah Penyakit (BNPB, 2015). Bencana alam dapat terjadi setiap saat dan tanpa peringatan tanpa sekali. Ketika terjadi bencana, pada umumnya orang akan berada dalam keadaan shock atau panik.

\subsection{Gempa bumi}

Gempa bumi adalah peristiwa bergetarnya bumi akibat pelepasan energi di dalam bumi secara tiba-tiba yang ditandai dengan patahnya lapisan batuan pada kerak bumi.Energi yang dihasilkan dipancarkan ke segala arah berupa gelombang gempabumi sehingga efeknya dapat dirasakan sampai ke permukaan bumi (BMKG, 2015).Gempabumi merupakan gejala alamiah yang berupa gerakan goncangan atau getaran tanah yang ditimbulkan oleh adanya sumber-sumber getaran tanah akibat terjadinya patahan atau sesar akibat aktivitas tektonik, letusan gunungapi akibat aktivitas vulkanik, hantaman benda langit (misalnya meteor dan asteroid), dan/atau ledakan bom akibat ulah manusia (BNPB, 2012).

Indonesia terletak pada pertemuan tiga lempeng yaitu lempeng Eurasia, Lempeng Indo-Australia dan Lempeng Pasifik seperti tampak pada gambar 1. Penyebab 
gempabumi dapat berupa pergerakan lempeng-lempeng tektonik, aktivitas gunungapi, akibat meteor jatuh, longsoran (di bawah muka air laut), atau ledakan bom nuklir di bawah permukaan bumi (Nur, 2010; BMKG, 2015). Gempabumitektonikmerupakan gempabumi yang paling umum terjadi.

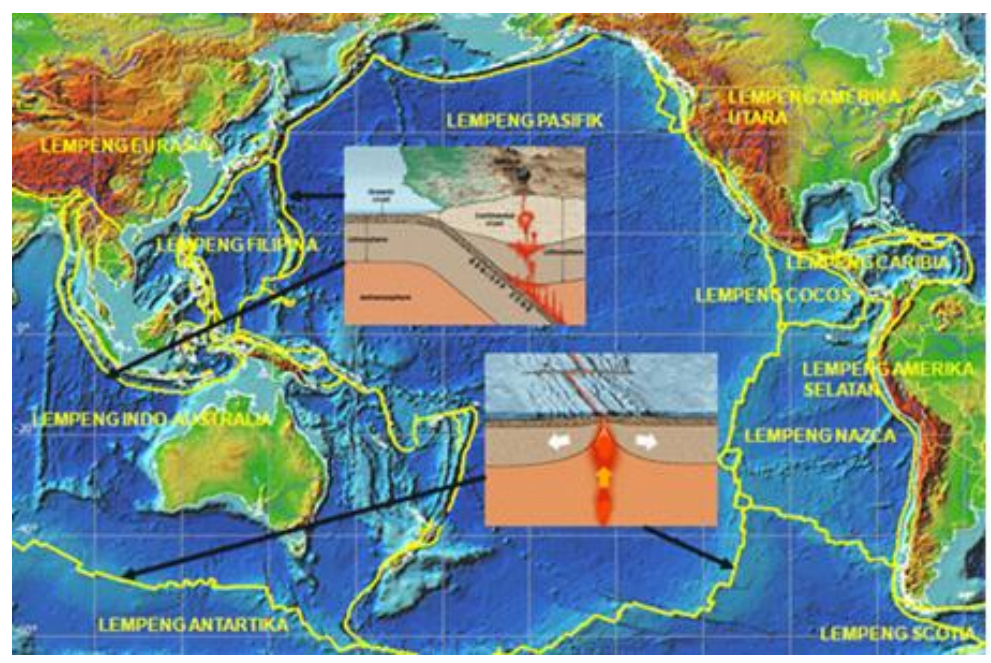

Gambar 1 Lempeng Indonesia dan Sekitarnya Sumber: BMKG, 2015

Jenis gempabumi dibagi menjadi 5, yaitu:

1. Gempabumi Tektonik adalah bergetarnya kerak hingga ke permukaan bumi karena pelepasan energi akibat tumbukan lempeng/pergerakan sesar (patahan);

2. Gempabumi Tumbukan merupakan gempa yang disebabkan oleh adanya tumbukan meteor atau asteroid yang jatuh ke bumi sehingga mengakibatkan bumi tergoncang. Akan tetapi, gempa jenis ini jarang terjadi;

3. Gempabumi Runtuhan merupakan gempabumi yang terjadi di daerah kapur atau daerah pertambangan. Sama seperti gempa bumi tumbukan, gempa bumi runtuhan juga sangat jarang terjadi;

4. Gempabumi Buatan merupakan gempabumi yang diakibatkan oleh aktivitas manusia, seperti peledakan dinamit, pelepasan nuklir, atau benda lain yang dipukulkan ke permukaan bumi sehingga menimbulkan goncangan besar;

5. Gempabumi Vulkanik merupakan gempabumi yang terjadi karena adanya aktivitas magma, yakni cairan yang biasanya muncul dari perut bumi sebelum gunung api meletus. Semakin tinggi keaktifan gunung api tersebut, maka kemungkinan ledakan yang ditimbulkannya akan semakin besar.

Gempabumi berdampak pada kerusakan gedung dan juga korban jiwa, yang berpengaruh secara langsung dan tidak langsung pada melemahnya perekonomian dan 
pertahanan pemerintahan.Oleh sebab itu, pengenalan dan pengurangan resiko bencana perlu dilakukan sejak dini untuk mengurangi risiko dan dampak negatif akibat bencana.

\subsection{Manajemen Bencana}

Manajemen bencana dapat diartikan sebagai sebuah proses siklus dari seluruh aktivitas yang mencakup, program kegiatan, kebijakan publik yang dilakukan pada saat sebelum, pada saat kejadian, dan setelah kejadian bencana, yang bertujuan untuk menghindari, meminimalisasi, dan memulihkan keadaan dari dampak bencana yang ditimbulkan (Yulianto, 2008). Banyaknya peristiwa bencana yang terjadi membuat pikiran terbuka bahwa manajemen bencana di negara Indonesia masih sangat jauh dari yang harapkan.Selama ini, manajemen bencana dianggap bukan prioritas dan hanya datang sewaktu-waktu saja,yang rawan terhadap ancaman bencana (Rachmat, 2015).

Terkait dengan manajemen penanggulangan bencana Undang-Undang No. 24 tahun 2007 tentang Penanggulangan Bencana menyatakan "Penyelenggaraan penanggulangan bencana adalah serangkaian upaya yang meliputi penetapan kebijakan pembangunan yang berisiko timbulnya bencana, kegiatan pencegahan bencana, tanggap darurat, dan rehabilitasi”. Rumusan penanggulangan bencana dari UU tersebut mengandung dua pengertian dasar yaitu:

1. Penanggulangan bencana sebagai sebuah rangkaian atau siklus;

2. Penanggulangan bencana dimulai dari penetapan kebijakan pembangunan yang didasari risiko bencana dan diikuti tahap kegiatan pencegahan bencana, tanggap darurat, dan rehabilitasi.

Menurut Perda Sumbar No. 5 tahun 2007 tujuan dari Manajemen Bencana adalah:

a. Memberikan perlindungan kepada masyarakat dari ancaman bencana;

b. Menyelaraskan peraturan perundang-undangan yang sudah ada;

c. Menjamin terselenggaranya penanggulangan bencana secara terencana, terpadu, terkoordinasi dan menyeluruh;

d. Menghargai budaya lokal;

e. Membangun partisipasi dan kemitraan publik serta swasta;

f. Mendorong semangat gotong royong, kesetiakawanan dan kedermawanan; dan

g. Menciptakan perdamaian dalam kehidupan bermasyarakat, berbangsa dan bernegara. 


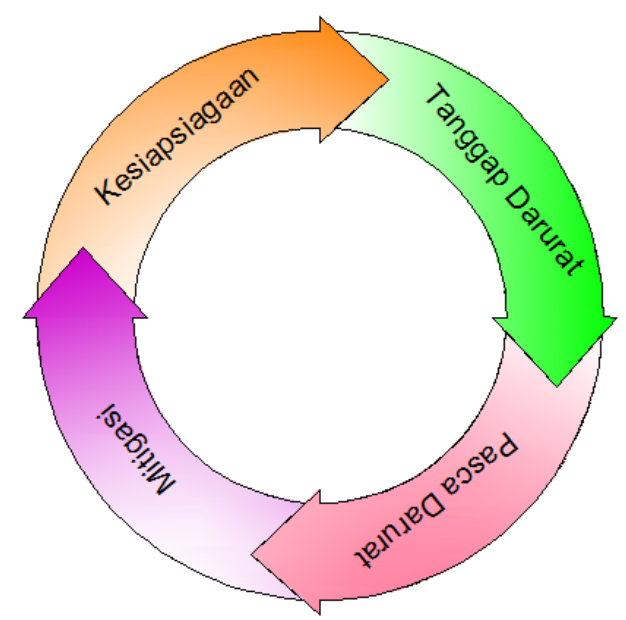

Gambar 2Siklus Penanggulangan Bencana

Sumber: Yulianto, 2008; LUTFIB, 2011; Juhri, 2015

Siklus Managemen Bencana atau Disaster Management Cycle adalah bentuk penerapan kegiatan dalam rangka mengatasi dan mempersiapkan diri menghadapi musibah (Yulianto, 2008). Siklus manajemen bencana terdiri dari 4 fase seperti Gambar 2 yaitu mitigasi (prevention), kesiapsiagaan (preparedness), tanggap darurat (response), pasca darurat (rehabilitation/reconstruction) (UNESCO, 2007; Hendritanoyo, 2011; Budianto, 2013). Keunggulan dari model ini adalah urutan kegiatan siklus dapat menggambarkan kebutuhan berupa tahapan mulai dari prabencana sampai dengan pascabencana (Yulianto, 2008).

\section{A. Mitigasi (Prevention)}

Undang-undang Republik Indonesia Nomor 24 Tahun 2007 mengenai Penanggulangan Bencana menyebutkan definisiMitigasi adalah serangkaian upaya untuk mengurangi risiko bencana, melalui pembangunan fisik maupun penyadaran dan peningkatan kemampuan menghadapi ancaman bencana. Kegiatan pada tahap pra bencana erat kaitannya dengan istilah mitigasi bencana yang merupakan upaya untuk meminimalkan dampak yang ditimbulkan oleh bencana.

Menurut Undang-undang Nomor 24 Tahun 2007 pasal 44 tentang Penanggulangan Bencana mitigasi dilakukan melalui:

a. pelaksanaan penataan ruang;

b. pengaturan pembangunan, pembangunan infrastruktur, tata bangunan; dan

c. penyelenggaraan pendidikan, penyuluhan, dan pelatihan secara konvensional maupun modern.

Upaya mitigasi dapat dilakukan dalam bentuk mitigasi strukturdengan memperkuat bangunan dan infrastruktur yang berpotensi terkena bencana, seperti 
membuat kode bangunan, desain rekayasa, dan konstruksi untuk menahan serta memperkokoh struktur ataupun membangun struktur bangunan penahan longsor, penahan dinding pantai, dan lain-lain. Selain itu upaya mitigasi juga dapat dilakukan dalam bentuk non struktural, diantaranya seperti menghindari wilayah bencana dengan cara membangun menjauhi lokasi bencana yang dapat diketahui melalui perencanaan tata ruang dan wilayah serta dengan memberdayakan masyarakat dan pemerintah daerah (Rachmat, 2015).

Mitigasi nonstruktural juga dapat dilakukan dengan memperkenalkan atau menerapkan asuransi bencana di daerah yang rawan gempa.Sehingga masyarakat tidak harus menunggu bantuan dari pemerintah atau donatur saat harus melakukan pemulihan pascabencana, terutama dari sisi ekonomi (Husein, 2009).Sebagai contoh usaha mitigasi adalah pembangunan sabo dam di wilayah Gunung Merapi sebagai antisipasi bahaya lahar dingin yang membawa material bebatuan.Upaya ini dilakukan untuk mengurangi jumlah material bebatuan yang dapat merusak tatanan kehidupan masyarakat secara sosial dan ekonomi (Yulianto, 2008).

\section{B. Kesiapsiagaan (Preparedness)}

Undang-undang Republik Indonesia Nomor 24 Tahun 2007 mengenai Penanggulangan Bencana menyebutkan definisikesiapsiagaan adalah serangkaian kegiatan yang dilakukan untuk mengantisipasi bencana melalui pengorganisasian serta melalui langkah yang tepat guna dan berdaya guna. Penanggulangan Bencana kesiapsiagaan dilakukan untuk memastikan upaya yang cepat dan tepat dalam menghadapi kejadian bencana. Kesiapsiagaan sebagaimana dimaksud dilakukan melalui:

a. penyusunan dan uji coba rencana penanggulangan kedaruratan bencana;

b. Pengorganisasian, pemasangan, dan pengujian sistem peringatan dini;

c. Penyediaan dan penyiapan barang pasokan pemenuhan kebutuhan dasar;

d. Pengorganisasian, penyuluhan, pelatihan, dan gladi tentang mekanisme tanggap darurat;

e. Penyiapan lokasi evakuasi ;

f. Penyusunan data akurat, informasi, dan pemutakhiran prosedur tetap tanggap darurat bencana; dan

g. Penyediaan dan penyiapan bahan, barang, dan peralatan untuk pemenuhan pemulihan prasarana dan sarana.

Upaya kesiapsiagaan adalah faktor penting dalam manajemen bencana dimana upaya ini dilakukan setelah usaha mitigasi dilaksanakan dengan baik.Tindakan relokasi dan pembangunan tempat-tempat pengungsian sehingga masyarakat yang rentan dapat 
menghindar di radius paling aman. Kesiapsiagaan bencana melibatkan semua lembaga, masyarakat dan individu, dimanasetiap pemangku kepentingan yang memiliki peran berbeda harus dipadukan untuk dapat mencapai kesiapsiagaan secara menyeluruh(Cindrawaty dan Nurul, 2015). Artinya, setiap lembaga dan masyarakat memiliki kewajiban dan peran dalam menanggulangi bencana dan menyiapkan diri untuk dapat menghadapi bencana dengan cepat dan tepat (Nurchayat, 2014).

Sebelum kejadian bencana gempa bumi perlu dilakukan persiapan dan pengetahuan mengenai kebencanaan. Hal ini dimaksudkan untuk menumbuhkan pemahaman dan kesiapsiagaan dalam menghadapi bencana sehingga diharapkan kerugian dan korban akan dapat dikurangi (Nur 2010). Pengetahuan dan persiapan (komponen) kesiapsiagaan bencana tersebut meliputi (KOGAMI, 2007; Yulianto, 2008; Nur, 2010; BMKG, 2015):

1. Mengenali apa yang disebut gempabumi, memahami daerah yang ditinggali merupakan daerah yang dekat dengan jalur gempa dan gunungapi sehingga perlunya sikap waspada dan kesiapsiagaan. Namun demikian tetap tenang dan hidup wajar seperti biasa;

2. Mengumpulkan informasi bencana yang diperkirakan terjadi di daerah tempat tinggal dengan menghubungi instansi yang berwenang atau terkait;

3. Memahami tempat-tempat yang aman dan tempat yang tidak aman apabila terjadi bencana gempa. Hal ini cukup penting dalam rangka tindakan penyelamatan diri saat kejadian bencana gempa;

4. Mengaitkan benda-benda berat yang membahayakan ke tempat yang kokoh sehingga bila terjadi gempa tidak mudah roboh atau jatuh yang dapat mencelakakan;

5. Mencatat nomor-nomor telepon darurat (seperti: pemadam kebakaran, polisi, ambulas, dll) dan tempatkan di tempat yang mudah terlihat didekat telepon dan jika memungkinkan, disimpan di dalam telepon genggam/ HP;

6. Pengembangan jaringan informasi dan sistem jaringan Sistem Peringatan Dini (Early Warning System/EWS);

7. Perbaikan terhadap infrastruktur yang dapat digunakan dalam keadaan darurat, seperti fasilitas komunikasi, jalan, kendaraan, gedung-gedung sebagai tempat penampungan; dll

8. Mengevaluasi dan merenovasi ulang struktur bangunan yang kuat terhadap gempabumi agar terhindar dari bahaya. Memastikan bahwa struktur dan letak rumah dapat terhindar dari bahaya yang disebabkan oleh gempabumi (longsor, liquefaction, dll); 
9. Membuat rencana jalur evakuasi (membuat peta jalur evakuasi) menuju satu titik tempat aman diluar bangunan dan persiapan stok kebutuhan pokok (suplai pangan, obat-obatan, dll);

10. Melakukan latihan evakuasi bagi masyarakat untuk menyelamatkan diri saat kejadian bencana. Hal ini penting untuk membiasakan melakukan evakuasi dan untuk mengestimasi waktu serta melakukan koordinasi saat kejadian bencana sebenarnya;

11. Mengenali Lingkungan Tempat Bekerja:memperhatikan letak pintu, lift serta tangga darurat, apabila terjadi gempabumi, sudah mengetahui tempat paling aman untuk berlindung, Belajar melakukan P3K, alat pemadam kebakaran, dan menggunakannya;

12. Mempersiapkan secara rutin tempat bekerja dan tinggal, seperti: perabotan (lemari, cabinet, dll) diatur menempel pada dinding (dipaku, diikat, dll) untuk menghindari jatuh, roboh, bergeser pada saaat terjadi gempabumi, menyimpan bahan yang mudah terbakar pada tempat yng tidak mudah pecah agar terhindar dari kebakaran, selalu mematikan air, gas dn listrik apabila tidak sedang digunakan;

13. Perlu Ditinjau kembali penyebab celaka yang paling banyak pada saat gempabumi adalah akibat kejatuhan material, maka benda yang berat sedapat mungkin diatur berada pada bagian bawah. Kestabilan benda yang tergantung yang dapat jatuh pada saat gempabumi terjadi (misalnya: lampu dll).

14. Alat yang harus ada di setiap tempat: kotak P3K, senter/lampu baterai, radio, makanan suplemen, dan air; dan

15. Peningkatan kemampuan dan keterampilan personil melalui pelatihan dan simulasi/latihan tanggap darurat.

C. Tanggap Darurat (Response)

Undang-undang Republik Indonesia Nomor 24 Tahun 2007 mengenai Penanggulangan Bencana menyebutkan definisitanggap darurat bencana adalah serangkaian kegiatan yang dilakukan dengan segera pada saat kejadian bencana untuk menangani dampak buruk yang ditimbulkan, yang meliputi kegiatan penyelamatan dan evakuasi korban, harta benda, pemenuhan kebutuhan dasar, perlindungan, pengurusan pengungsi, penyelamatan, serta pemulihan prasarana dan sarana. Upaya tanggap darurat adalah tindakan emergency sesaat setelah terjadi bencana.Upaya ini dapat meliputi usaha penyelamatan (rescue effort), first aid, fire fighting, dan evakuasi.Seluruh tindakan diupayakan untuk menekan dan mengurangi jumlah korban (Yulianto, 2008). Menurut Undang-undang Nomor 24 Tahun 2007 Pasal 46 tentang Penanggulangan Bencana tanggap darurat bencana dilakukan melalui: 

a. Pengamatan gejala bencana;
b. Analisis hasil pengamatan gejala bencana;
c. Pengambilan keputusan oleh pihak yang berwenang;
d. Penyebarluasan informasi tentang peringatan bencana; dan
e. Pengambilan tindakan oleh masyarakat.
D. Pasca Darurat (Rehabilitation/Recontruction)

Undang-undang Republik Indonesia Nomor 24 Tahun 2007 mengenai Penanggulangan Bencana menyebutkan definisipasca darurat terdiri dari rehabilitasi dan rekonstruksi. Rehabilitasi adalah perbaikan dan pemulihan semua aspek pelayanan publik atau masyarakat sampai tingkat memadai pada wilayah pascabencana dengan sasaran utama untuk normalisasi atau berjalannya secara wajar semua aspek pemerintahan dan kehidupan masyarakat pada wilayah pasca bencana.Rekonstruksi adalah pembangunan kembali semua prasarana dan sarana, kelembagaan pada wilayah pascabencana, baik pada tingkat pemerintahan maupun masyarakat dengan sasaran utama tumbuh dan berkembangnya kegiatan perekonomian, sosial dan budaya, tegaknya hukum dan ketertiban, dan bangkitnya peran serta masyarakat dalam segala aspek kehidupan bermasyarakat pada wilayah pascabencana.

Pemulihan adalah serangkaian kegiatan untuk mengembalikan kondisi masyarakat dan lingkungan hidup yang terkena bencana dengan kembali kelembagaan, prasarana, dan sarana dengan melakukan rehabilitasi. Menurut Undang-undang Nomor 24 Tahun 2007 pasal 58 tentang Penanggulangan Bencana pasca darurat pada elemen rehabilitasi dan rekonstruksi dilakukan melalui:
a. Perbaikan lingkungan daerah bencana;
b. Perbaikan prasarana dan sarana umum;
c. Pemberian bantuan perbaikan rumah masyarakat;
d. Pemulihan sosial psikologis;
e. Pelayanan kesehatan;
f. Rekonsiliasi dan resolusi konflik;
g. Pemulihan sosial ekonomi budaya;
h. Pemulihan keamanan dan ketertiban;
i. Pemulihan fungsi pemerintahan; dan
j. Pemulihan fungsi pelayanan publik.

Fase pada siklus bencana memiliki porsi masing-masing dalam kegunaan perannya.Keseriusan melakukan seluruh elemen sangat mempengaruhi berkurangnya 
risiko saat terjadi bencana.Kesiapsiagaan adalah salah satu elemen dari siklus penanggulangan bencana yang berperan dalam mengatisipasi sebelum terjadinya bencana guna mengurangi risiko akibat terjadinya bencana.

\section{STUDI KASUS}

Metode kuantitatif digunakan dalam melakukan pengambilan data yang diperlukan untuk penelitian.Penelitian kuantitatif menggunakan alat-alat atau instrumen untuk mengukur gejala-gejala tertentu secara statistik. Teknik penelitian kuantitatif juga dilakukan dengan cara eksperimen, survey, dan wawancara. Instrumen yang digunakan dalam penelitian adalah penyebaran angket (kuesioner), skala, kamera digital, alat tulis, danperekam suara (S.R. Pupu,2012).Tetapi dalam perkembangannya data yang berupa angka dan pengolahan matematis kurang dan atau tidak dapat menerangkan kebenaran secara menyakinkan. Oleh karena itu digunakan metode kualitatif yang dianggap mampu mereangkan gejala atau fenomena secara lengkapdan menyeluruh. Metode kualitatif adalah salah satu prosedur penelitian yang menghasilkan data deskriptif berupa ucapan atau tulisan dan perilaku yang diamati (S.R. Pupu,2012).

Data siaga bencana gempa diperoleh melalui observasi lapangan dengan pengambilan foto menggunakan kamera digital, wawancara dilakukan kepada pihak yang berpengaruh atau pejabat struktural di Gedung Pendidikan tersebut untuk meninjau kesiapsiagaan gedung dari sudut pandang pemimpin, dan juga melalui penyebaran kuesioner kepada pengguna gedung untuk mengetahui pendapat dari pengguna gedung akan kesiapsiagaan Gedung Pendidikan terhadap bencana gempa.

\subsection{Kuesioner Siaga Bencana Gempa}

Kuesioner merupakan salah satu instrumen penelitian kesiapsiagaan bangunan terhadap bencana gempa.Populasi penelitian adalah pengguna Gedung Pendidikan yang termasuk di dalamnya adalah Guru, Karyawan, dan Siswa. Gambaran populasi penelitian adalah jumlah Guru sebanyak 72 orang, Karyawan sebanyak 33 orang, dan Siswa sebanyak 1174 orang.Evaluasi kesiapsiagaan dan Pengisian sistem pengolahan data kuesioner dilakukan dengan bantuan Google Formdalam bentuk link yaitu http://goo.gl/forms/a7Rf2KWIfHyang disebarkan kepada pengguna Gedung Teknik melalui internet yang terhubung.Serangkaian langkah untuk menyusun pertanyaan wawancara dan kuesioner menggunakan beberapa referensi terkait seperti ditampilkan padaTabel1. Berikut merupakan langkah-langkah membuat kuesioner:

a. Menentukan topik dan tujuan kuesioner 
Topik kuesioner penelitian adalah siaga bencana gempabumi.Kuesioner bertujuan untuk mengetahui kesiapsiagaan bangunan Gedung

Pedidikanmelaluipenilaianpenggunagedung.

b. Menentukan variabel kuesioner

Variabel dalam kuesioner dibagi menjadi tiga yaitu pengetahuan, tindakan, kesiapsiagaan. Setiap variabel dalam kuesioner memiliki sub-variabel agar pengelompokkan data lebih detail dan mudah dimengerti oleh responden ketika mengisi kuesioner.

Kuesioner yang disebarkan memiliki 4 bagian yaitu bagian profil/data responden, pengetahuan, tindakan, dan kesiapsiagaan.Pengetahuan responden mengenai bangunan siaga bencana gempabumi akan mempengaruhi penilaian responden terhadap kesiapsiagaan bangunan siaga bencana gempabumi. Tindakan responden ketika terjadi gempabumi merupakan wujud pengetahuan responden mengenai gempabumi yang dituangkan pada tindakan nyata.Kesiapsiagaan bangunan terhadap gempabumi, disertai pertanyaan mendetail pada kuesioner.Pertanyaan kesiapsiagaan jalur rambu evakuasi pada kuesioner mengenai sub-variabel kesiapsiagaan dapat menentukan kesiapsiagaan bangunan terhadap siaga bencana gempabumi.

Metode yang digunakan dalam penelitian ini adalah metode deskriptif analitis.Metode deskriptif analitis lebih memusatkan perhatian pada fenomena yang sedang terjadi pada saat penelitian dilakukan, dimana penelitian ini berusaha untuk membuat deskriptif fenomena yang diselidiki dengan melukiskan fakta tersebut. Rumusananalisis data dalam kajian ini menggunakan diagram persentase.

Tabel 1. Referensi Kuesioner

\begin{tabular}{|c|l|l|}
\hline Variabel & \multicolumn{1}{|c|}{ Pertanyaan } & \multicolumn{1}{|c|}{ Sumber } \\
\hline Pengetahuan & Bencana gempabumi membutuhkan penanganan secara & KOGAMI \\
& kualitatif. & 2007; Nur, \\
\cline { 2 - 3 } & A.M, 2010; & Dalimunte, R.F, \\
\cline { 2 - 3 } & pempabumi adalah peristiwa terguncangnya & $2011 ;$ \\
\cline { 2 - 3 } & ENmukaan bumi yang dirasakan secara tiba-tiba. & $2012 ; 2007 ;$ \\
\cline { 2 - 3 } & Gempabumi tektonik. & Presiden, 2008; \\
\cline { 2 - 3 } & Gempabumi vulkanik. & $2008 ;$ BNPB, \\
\cline { 2 - 3 } & Perilaku hewan yang aneh adalah tanda gempabumi. & $2014 ;$ BNPB, \\
\cline { 2 - 3 } & Alat pencatat gempabumi merupakan seismograf. & \\
\cline { 2 - 3 } & Lari keluar gedung saat terjadi gempabumi. & \\
\hline
\end{tabular}




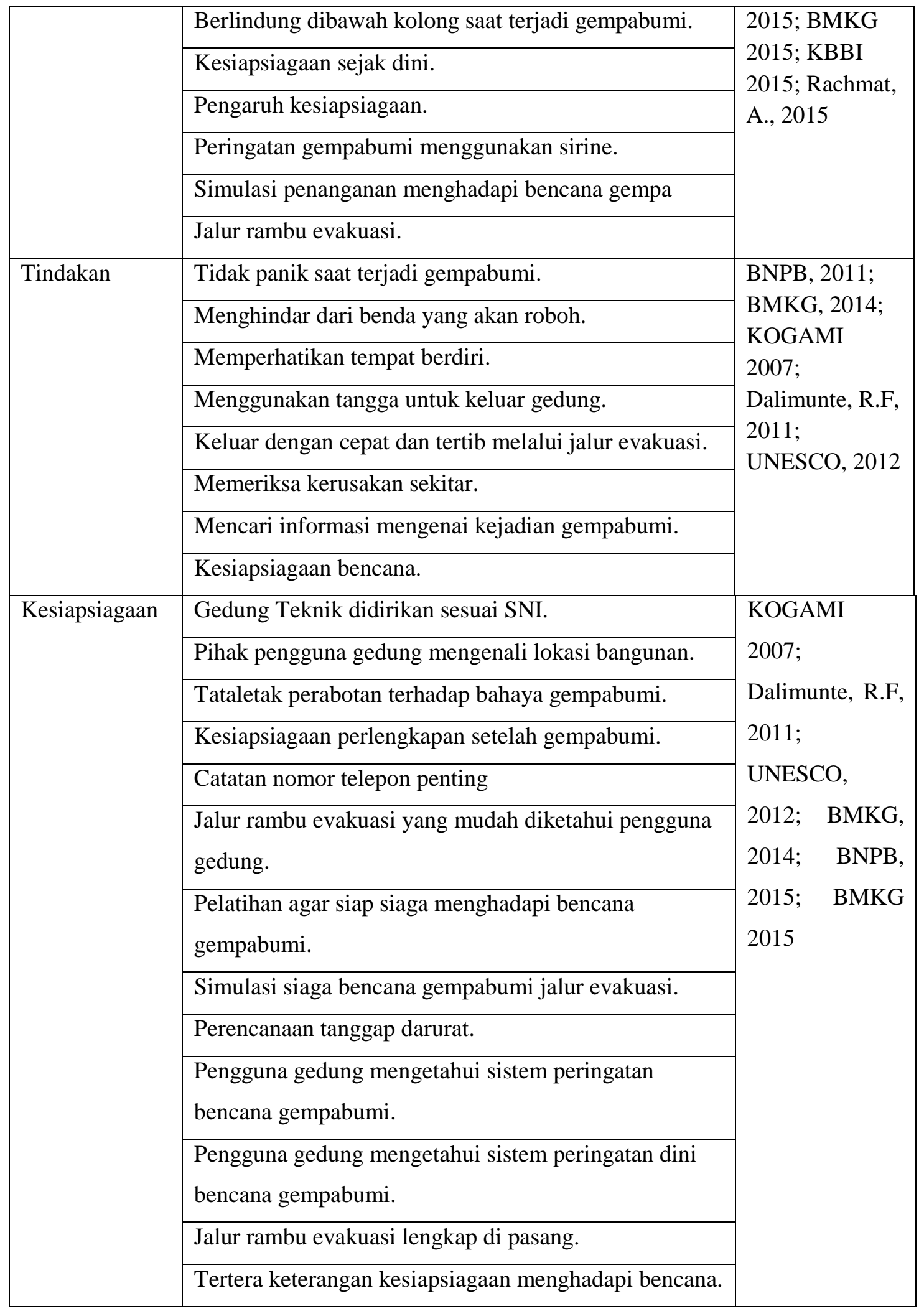


Tabel 1.Referensi Kuesioner (Lanjutan)

\begin{tabular}{|l|l|c|}
\hline \multicolumn{1}{|c|}{ Variabel } & \multicolumn{1}{|c|}{ Pertanyaan } & \multicolumn{1}{|c|}{ Sumber } \\
\hline \multirow{3}{*}{} & $\begin{array}{l}\text { Pengguna gedung mengetahui sistem peringatan dini } \\
\text { bencana gempabumi. }\end{array}$ & \\
\cline { 2 - 2 } & Jalur rambu evakuasi lengkap di pasang. & \\
\cline { 2 - 2 } & Tertera keterangan kesiapsiagaan menghadapi bencana. & \\
\cline { 2 - 2 } & $\begin{array}{l}\text { Pengguna gedung mengetahui sistem peringatan dini } \\
\text { bencana gempabumi. }\end{array}$ & \\
\cline { 2 - 3 } & Jalur rambu evakuasi lengkap di pasang. & \\
\hline
\end{tabular}

\subsection{Wawancara}

Wawancara adalah teknik pengumpulan data yang dilakukan dengan bercakapcakap dengan sumber data secara langsung maupun tidak langsung. Teknik wawancara bertumpu kepada faktor manusia sebagai alat pengumpul data.Wawancara pada penelitian ini dilakukan dengan bercakap-cakap secara langsung dengan sumber data.Informasi diperoleh dalam suasana komunikasi secara langsung yang memungkinkan seseorang memberikan data faktual seperti mengungkapkan sikap, pikiran, harapan, dan perasaan.

Pertanyaan-pertanyaan wawancara yang diajukan merupakan pertanyaan yang berasal dari kuesioner sebagai referensi atau sumber pertanyaan. Pelaksanaan wawancara menggunakan alat bantu perekam suara, kertas dan alat tulis yang mempermudah proses pengumpulan data wawancara. Fleksibel, pelaksanaanya dapat disesuaikan dengan masing-masing responden sebagai data wawancara.Kesiapsiagaanbangunanterhadapbahayagempaditinjaumelaluitiga variable yaitu Pengetahuan, Tindakan, dan Kesiapsiagaan.Data wawancara dikumpulkandaripejabat struktural Gedung Pendidikan untuk meninjau kesiapsiagaan Gedung Pendidikan dari sudut pandang pemangkukepentingan.

\section{ANALISIS DATA DAN PEMBAHASAN}

\subsection{Analisis Wawancara}

A. Pengetahuan

Wawancara dilakukan kepada 3 responden memiliki status yang berpengaruh terhadap Gedung Pendidikan ataupun kepada para pengguna Gedung Pendidikan.Responden wawancara telah menjadi pengguna Gedung Pendidikan lebih dari 15 tahun.Daftar pertanyaan wawancara mencakup instrumen pertanyaan yang menunjukkan data responden. 
"Apakah Gedung merupakan Gedung Tahan Gempa?", "Apakah Gedung merupakan Gedung Siaga Bencana Gempa?" dan “Apakah gempabumi berbahaya?" merupakan instrumen pertanyaan yang mendeskripsikan variabel pengetahuan.Responden memiliki persepsi masing-masing mengenai bahaya gempabumi terhadap bangunan. Responden menyatakan gempa bumi merupakan kejadian berbahaya.Responden menyebutkan kata "tergantung" untuk menegaskan bahwa bahaya gempabumi yang berkaitan dengan penelitian bangunan siaga bencana gempatidak serta merta merupakan hal yang berbahaya.Tingkat bahaya gempabumi terhadap bangunan ditentukan oleh seberapa besar kekuatan gempabumi tersebut.

Pada umumnya bangunan didirikan dengan kaidah-kaidah yang berlaku, sesuai dengan Standar Nasional Indonesia (SNI).Perencanaan bangunan tahan gempa menggunakan SNI 1726:2012. Gempabumi yang terjadi tidak dapat diprediksi sehingga jika kekuatan gempa melebihi kapasitas desain maka kemungkinan besar bangunan akan rubuh/hancur sehingga dapat menimbulkan kerugian jiwa, harta dan benda.

"Apakah bapak/ibu pernah mendengar mengenai bangunan siaga bencana gempa?", reponden pernah mendengar mengenai bangunan siaga bencana gempa. Pendapat Responden adalah bangunan siaga bencana gempa merupakan bangunan yang kuat saat mengalami gempa sesuai dengan kekuatan desain.Sehingga dapat meminimalisir rasa "kaget dan bingung" para pengguna gedung ketika menghadapi kejadian gempabumi yang melebihi desain perhitungan bangunan tahan gempa.

B. Tindakan

"Jika terjadi gempabumi ketika bapak/ibu sedang berada dalam Gedung Pendidikan apa yang akan bapak/ibu lakukan?pertanyaan yang mendeskripsikan variabel tindakan. Ada berbagai spontanitas saat gempa terjadi, seperti merasa "kaget", "bengong", "bingung", "pasrah", atau bahkan langsung bertindak melakukan penyelamatan diri dengan lari keluar gedung. Perasaan tersebut timbul dipengaruhi oleh pengetahuan mengenai siaga bencana gempa.Merasa "aman" karena "pengalaman" merasakan gempabumi saat berada di Gedung Pendidikan tidak berdampak negatif terhadap bangunan.Bangunan tetap berdiri tanpa adanya kerusakan dari dampak gempabumi yang terjadi.

Tindakan penyelamatan diri dari bahaya gempabumi seringkali membuat penguna gedung tidak dapat keluar dari gedung adalah dengan pergi ke kolong meja atau kursi.Gempabumi terjadi secara mendadak sehingga perlu dilakukan kesiapsiagaan sejak awal.Sejak saat bangunan didirikan.Mendirikan bangunan siaga bencana gempa yang lengkap jalur rambu evakuasi.Bangunan didirikan sesuai perencanaan bangunan tahan 
gempa SNI 1726:2012.Maka ketika sewaktu-waktu gempa terjadi tindakan yang dilakukan adalah tanggap bencana gempa dan melakukan penyelamatan diri dengan tepat secara maksimal.

\section{Kesiapsiagaan Bangunan}

Menurut Undang-undang Republik Indonesia Nomor 24 Tahun 2007 mengenai Penanggulangan Bencana.Kesiapsiagaan adalah serangkaian kegiatan yang dilakukan untuk mengantisipasi bencana melalui pengorganisasian serta melalui langkah yang tepat guna dan berdaya guna.Negara Indonesia merupakan negara daerah rawan gempa sehingga perlu dilakukan latihan simulasi bencana secara berkala.Melakukan upaya kesiapsiagaan sehingga dapat mengurangi timbulnya kerugian.

Pertanyaan wawancara "Apakah Gedung Pendidikan merupakan gedung tahan gempa?", menyatakan pendapat responden mengenai bangunan tahan gempa terhadap Gedung Pendidikan. Pengalaman terjadinya gempabumi yang dirasakan pada Gedung Pendidikan membuat persepsi responden bahwa Gedung Pendidikan merupakan bangunan gedung tahan gempa.Tidak ada terjadi kerusakan yang berarti.Kegiatan para pengguna gedung tetap berjalan tak ada hambatan.Bangunan gedung tetap berdiri dan digunakan sesuai pemanfaatan seperti biasa.

“Apakah Gedung Pendidikan merupakan gedung yang siaga bencana gempa?", pertanyaan pada wawancara menyatakan penilaian responden mengenai bangunan tahan gempa terhadap Gedung Pendidikan. Responden menyatakan "belum", berarti bahwa terpikirkan oleh responden untuk melengkapi dengan instrumen/atribut siaga bencana gempa. Pemeliharaan gedung kurang diperhatikan dapat dilihat dari banyaknya pintu yang dikunci tanpa alasan yang jelas, sehingga bagi responden Gedung Pendidikan merupakan gedung "tidak" siaga bencana gempa. Bangunan tidak siaga bencana gempa memberi dampak pada para pengguna gedung tidak siap menghadapi bencana gempabumi, meskipun berdirinya bangunan sudah memenuhi Standar Nasional Indonesia (SNI) yang berlaku.Kelengkapan bangunan siaga bencana gempa dipersiapkan sejak awal bangunan berdiri.Memberi kesiapan diri menghadapi bencana gempa bumi.

\subsection{Analisis Kuesioner}

Proses pengumpulan data melalui kuesioner yang disebarkan pada seluruh pengguna Gedung Pendidikanselama 1 bulan. Jumlah Karyawan adalah 33 orang, Guru adalah 72 orang, dan Siswaadalah 1174 orang. Kuesioner disebar dalam 4 bagian yaitu data responden dan 3 variabel kuesioner yang terdiridari: variabel pengetahuan, variabel tindakan dan variabel kesiapsiagaan. Kuesioner disebarkan dengan tujuan untuk mengetahui kesisapsiagaan pengguna Gedung 
Pendidikan terhadap siaga bencana gempa dengan masing-masing variabel yang telah ditentukan.Kesiapsiagaan terhadap bencana adalah bagian dari keterampilan untuk kelangsungan hidup sehingga kesiapsiagaan harus menjadi bagian materi yang diberikan dalam dunia pendidikan (UNESCO, 2009).

Jumlah responden kuesioner yang terkumpulterdiri dari 182 responden yang terdiri atas 114 orang $(62,6 \%)$ pria dan 68 orang $(37,4 \%)$ wanita.Respondenterdiridari 97 orang $(53,3 \%)$ berumur $21-25$ tahun; 14 orang $(7,7 \%)$ berumur $26-20$ tahun; dan 71 orang (39\%) berumur 15-20 tahun. Berdasarkanprofesinya, 20orang (11\%) responden berprofesi karyawan; 15 orang $(8,2 \%)$ responden berprofesi lainnya; dan 147 orang $(80,8$ $\%)$ responden berprofesi siswa. Pendidikan terakhir para responden adalah 8 orang $(4,4 \%)$ responden berpendidikan terakhir Sekolah Menangah Pertama; 122 orang (67\%) responden berpendidikan terakhir Sekolah Menengah Atas; 46 orang $(25,3 \%)$ responden berpendidikan terakhir S-1; 4 orang $(2,2 \%)$ responden berpendidikan terakhir S-2; dan 2 orang $(1,1 \%)$ responden berpendidikan terakhir lainnya.

Tabel 2. Lama Responden Menggunakan Gedung

\begin{tabular}{|c|c|c|}
\hline Jumlah Responden & Waktu & Persentase \\
\hline 33 orang & $>1$ tahun & $18,1 \%$ \\
\hline 88 orang & $1-3$ tahun & $48,4 \%$ \\
\hline 51 orang & $4-6$ tahun & $28 \%$ \\
\hline 5 orang & $7-9$ tahun & $2,7 \%$ \\
\hline 5 orang & lainnya & $2,7 \%$ \\
\hline
\end{tabular}

"Pelatihan Penanganan gawat darurat yang pernah diikuti?" merupakan pertanyaan terakhir data responden pengisi kuesioner. Beberapa responden pernah mengikuti pelatihan gawat darurat yaitu dari (Badan Penanggulangan Bencana Daerah) BPBD, penanganan gempa tektoknik, simulasi darurat gempa dan tsunami Cirebon, Save Our Soul (SOS), Usaha Kesehatan Sekolah (UKS), Searchand Rescue (SAR), kegiatan naik gunung, kebakaran, banjir, dan Palang Merah Remaja (PMR). Pelatihan gawat darurat yang diikuti merupakan pelatihan yang dimana penyelenggara bukanlah Gedung Pendidikan.Dua responden pernah mengikuti pelatihan gawat darurat yaitu pelatihan Gempabumi dan satu responden menjawab belum pernah mengikuti pelatihan yang diadakan oleh pengelolagedung.Sebanyak 170 responden lainnya belum pernah mengikuti pelatihan penanganan gawat darurat ditempat manapun. 


\section{A. Pengetahuan}

Hasil variabel pengetahuan responden secara grafis dapat dilihat pada gambar 3.Gambar meliputi seluruh hasil kuesioner yang digambarkan dalam bentuk grafik.Pengetahuan responden mengenai bencana gempabumi mencapai angka 80\%.Gambar 3menyatakan bahwa responden mengetahui arti kata gempabumi, jenisjenis gempabumi dan bahaya gempabumi.Gempabumi adalah peristiwa terguncangnya permukaan bumi yang dirasakan secara tiba-tiba (BMKG, 2015; BNPB, 2012).
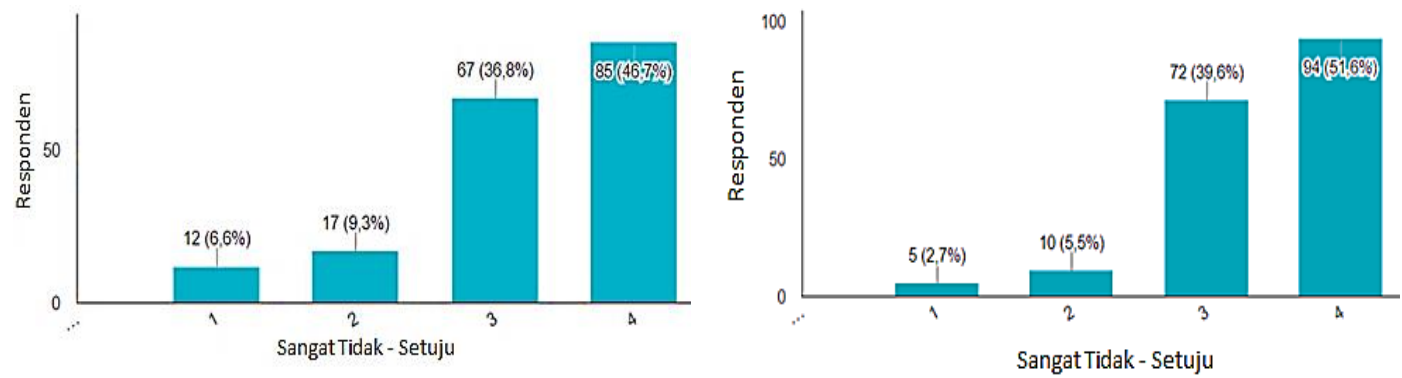

a. Definisi gempabumi

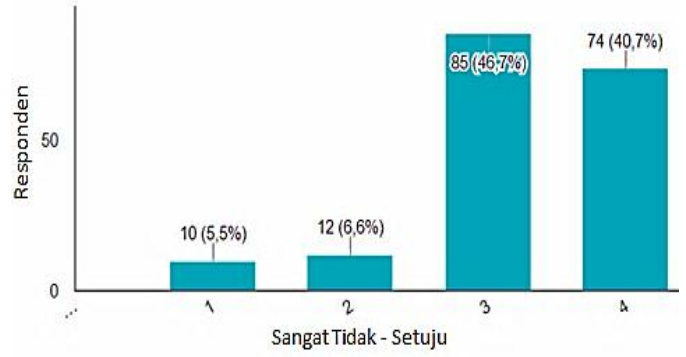

b. Peristiwagempabumi

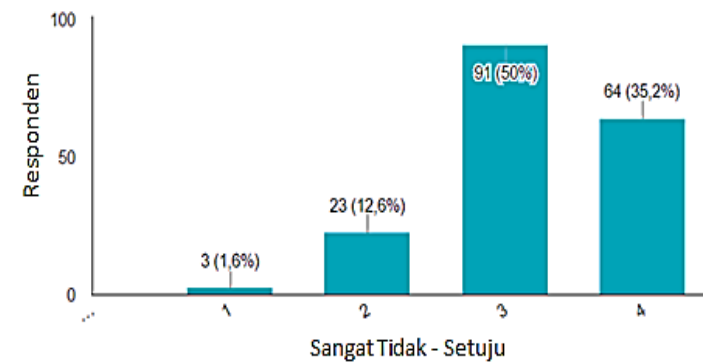

c. Penanganan secara kualitatif terhadap

d. Definisi gempabumi vulkanik siaga bencana
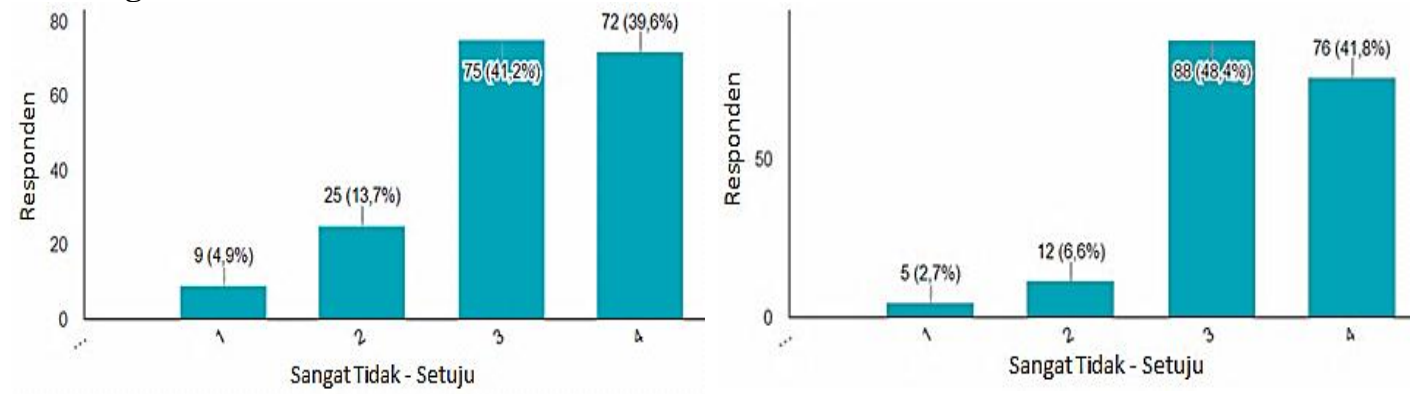

e. Kedatangan gempabumi

f. Banyaknya penduduk bermukim di wilayah rawan gempabumi
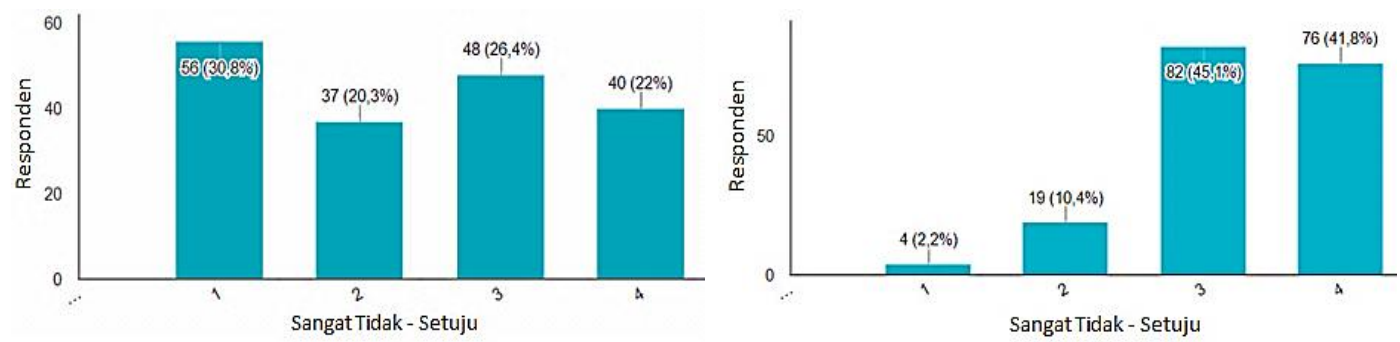

g. Kegunaan alat seismograf

h. Definisi gempabumi tektonik

Gambar 3. Grafik Hasil Analisis Deskriptif Persentase Variabel Pengetahuan 

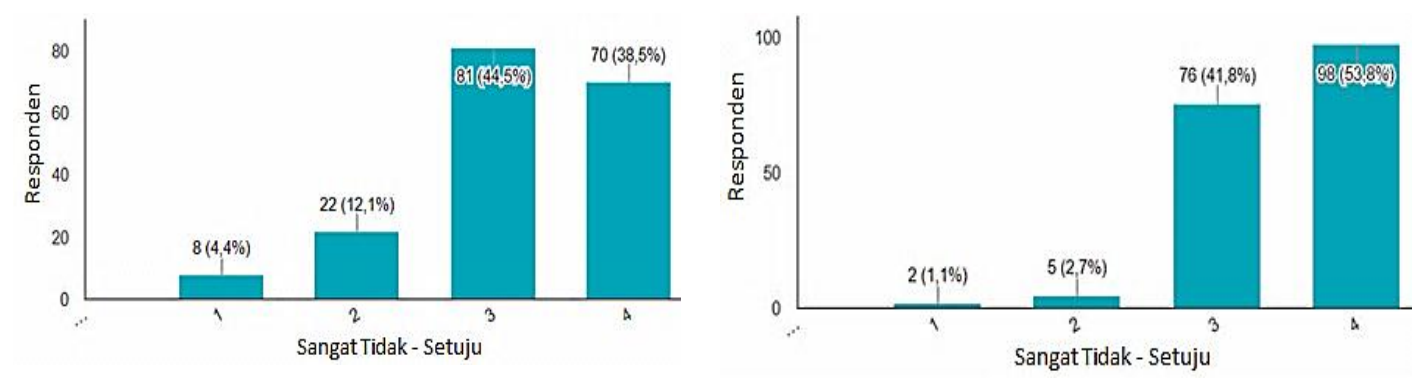

i. Tanda gempa melalui perilaku hewan

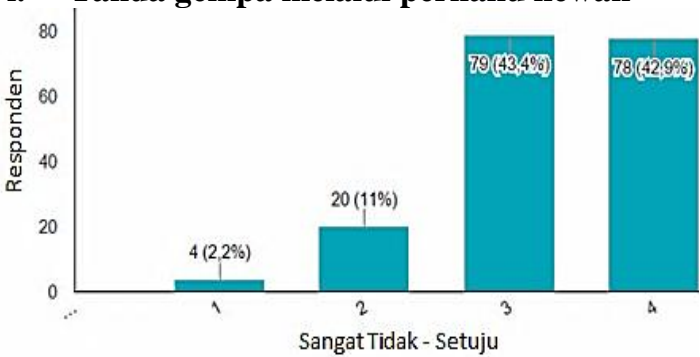

j. Kerugian akibat gempabumi

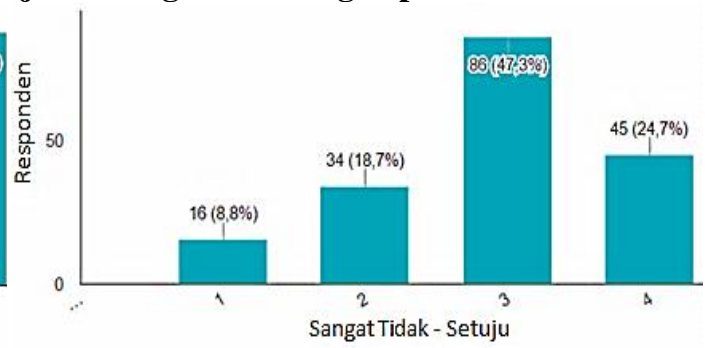

k. Pengetahuan tindakan penyelamatan diri

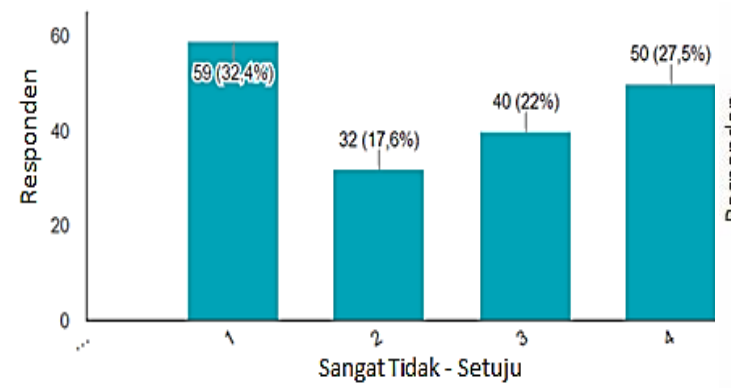

1. Tas, Panci atau Bantal sebagai alat pelindung

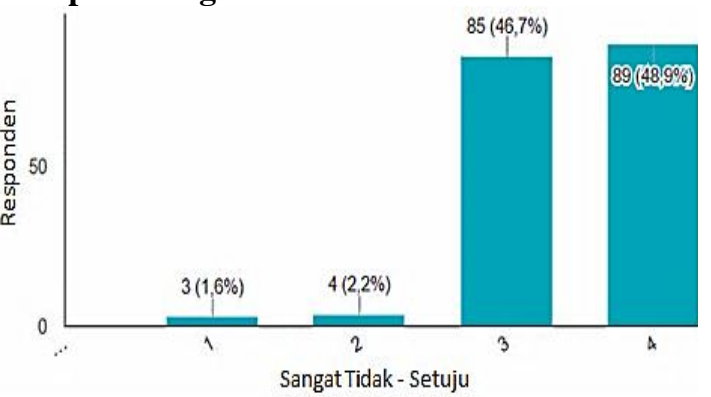

m. Bahaya gempabumi

n. Kewaspadaan daerah rawan

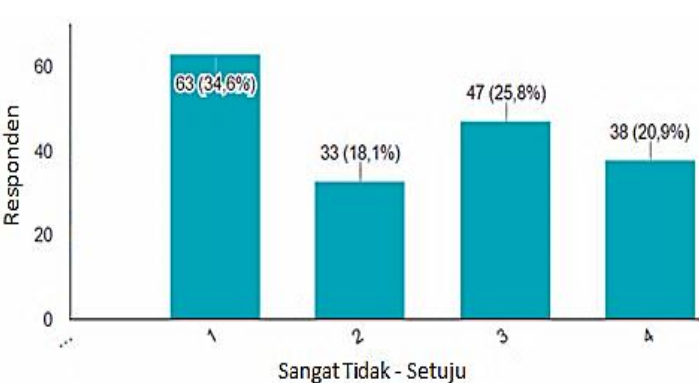
becanagempabumi

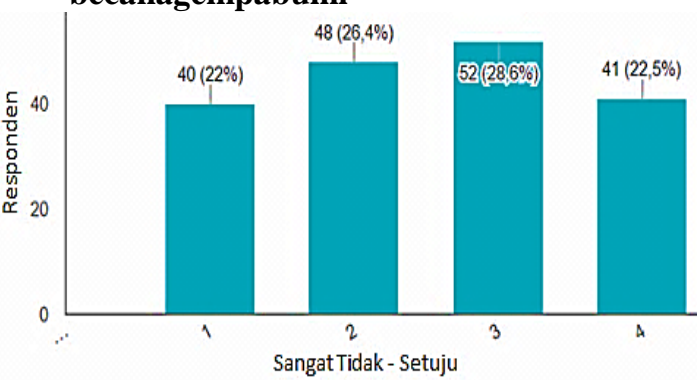

o. Tindakan berlindung yang aman di bawah meja yang rusak

p. Kesiapsiagaan mengurangi resiko

Gambar 3 Grafik Hasil Analisis Deskriptif Persentase Variabel Pengetahuan (Lanjutan)

Pengetahuan responden mengenai tanggap siaga bencana gempa dan kesiapsiagaan bangunan terhadap gempa serta kesiapsiagaan responden terhadap gempa ditunjukan pada gambar 3.Pengetahuan responden mencapai $80 \%$ menyatakan bahwa kewaspadaan sejak dini penting untuk ditingkatkan guna meningkatkan kesiapsiagaan menghadapi bencana gempabumi. Perbedaan hasil kuesioner dengan angka 2,7\% untuk pengetahuan mengenai alat seismograf pada 3 dengan pertanyaan mengenai banyaknya 
penduduk bermukim di wilayah rawan gempabumi. Angka tertinggi dicapai oleh responden yang tidak mengetahui bahwa seismograf merupakan alat pencatat gempabumi (KBBI, 2015).

Hanya $51 \%$ responden menyatakan bahwa kesiapsiagaan bencana mempengaruhi upaya mengurangi resiko bencana dapat dilihat pada pernyataan mengenai kesiapsiagaan mengurangi resiko.Menurut Undang-undang Republik Indonesia Nomor 24 Tahun 2007 mengenai Penanggulangan Bencana.Bencana adalah rangkaian peristiwa mengancam dan mengganggu kehidupan masyarakat yang disebabkan oleh faktor alam, faktor non alam ataupun faktor manusia. Bagian kuesionerpada gambar 3adalah 61,5\% responden dinyatakan mengetahui bahwa sistem peringatan jika terjadi bencana dalam sebuah gedung adalah adanya bunyi sirine. Gedung Pendidikan sebagai tempat responden berkegiatan sehari-harinya harus tersedia sirinedidalam gedung sebagai prasarana siaga bencana yang dapat terjadi kapan saja.

Lebih dari 90\% responden mengetahui bahwa jalur rambu evakuasi lengkap terpasang merupakan bentuk dari bangunan siaga bencana gempabumi. Gedung Pendidikan digunakan sebagai gedung pendidikan tinggi. Gedung Pendidikan merupakan tempat mengembangkan diri dalam keterampilan dan ilmu pengetahuan. Keberadaan jalur rambu evakuasi membantu terciptanya gedung pendidikan yang memberi rasa aman bagi pengguna gedung.

Pengetahuan responden mengenai bangunan tidak siaga bencana gempa yang menimbulkan kerugian mencapai angka lebih dari 90\%. Apabila tidak memiliki pengetahuan tentang bangunan siaga bencana gempa maka besarnya tingkat kesiapsiagaanpun rendah. Hasil variabel pengetahuan menyatakan bahwa responden mengetahui tentang bangunan siaga bencana gempa meliputi hal-hal yang berhubungan gempa seperti arti kata, jenis, bahaya gempa dan hal-hal lainnya yang tersusun pada kuesioner.Pengetahuan mengenai siaga bencana gempa menimbulkan perasaan tidak asing dengan bahasan mengenai bencana gempa diantara para responden sebagai pengguna Gedung Pendidikan.

\section{B. Tindakan}

Indonesia merupakan daerah rawan gempabumi (BMKG, 2015).Berbagai macam ancaman bencana gempabumi dapat terjadi di wilayah Indonesia.Banyak tindakan yang harus dilakukan saat terjadi gempabumi.Tindakan tepat dengan mengetahui prioritas tindakan saat terjadi gempabumi dapat meminimalisir risiko. 
Gambar 4 merupakan gambar grafik hasil kuesioner varibel tindakan responden.Tabel meliputi seluruh hasil kuesioner variabel tindakan yang digambarkan dalam bentuk grafik.Hasil kuesioner variabel tindakan dipengaruhi oleh pengetahuan responden mengenai bangunan siaga bencana gempa.

Gambar 4.a dengan pernyataan kuesioner "menguasai diri saat gempabumi" menyatakan lebih dari $90 \%$ responden menyatakan tidak panik.Kepanikan timbul secara natural saat gempabumi terjadi.Gempabumi tidak seharusnya dihadapi dalam keadaan panik (KOGAMI, 2007).Kepanikan hanya memperburuk situasi akibat bencana gempabumi.Menghadapi bencana dalam keadaan panik dapat menambah atau menciptakan bencana baru.

"Menghindar dari bagian bangunan yang berpotensi roboh dan menimpa kita." Merupakan pertanyaan kuesioner variabel tindakan yang memperoleh hasil 40,7\% setuju dan 56,6\% sangat setuju. Tindakan cepat, tepat dan tertib saat terjadi gempa merupakan pilihan yang dapat mengurangi risiko bencana, maka menghindari bangunan yang mungkin roboh dilakukan dengan cepat, tepat dan tertib.
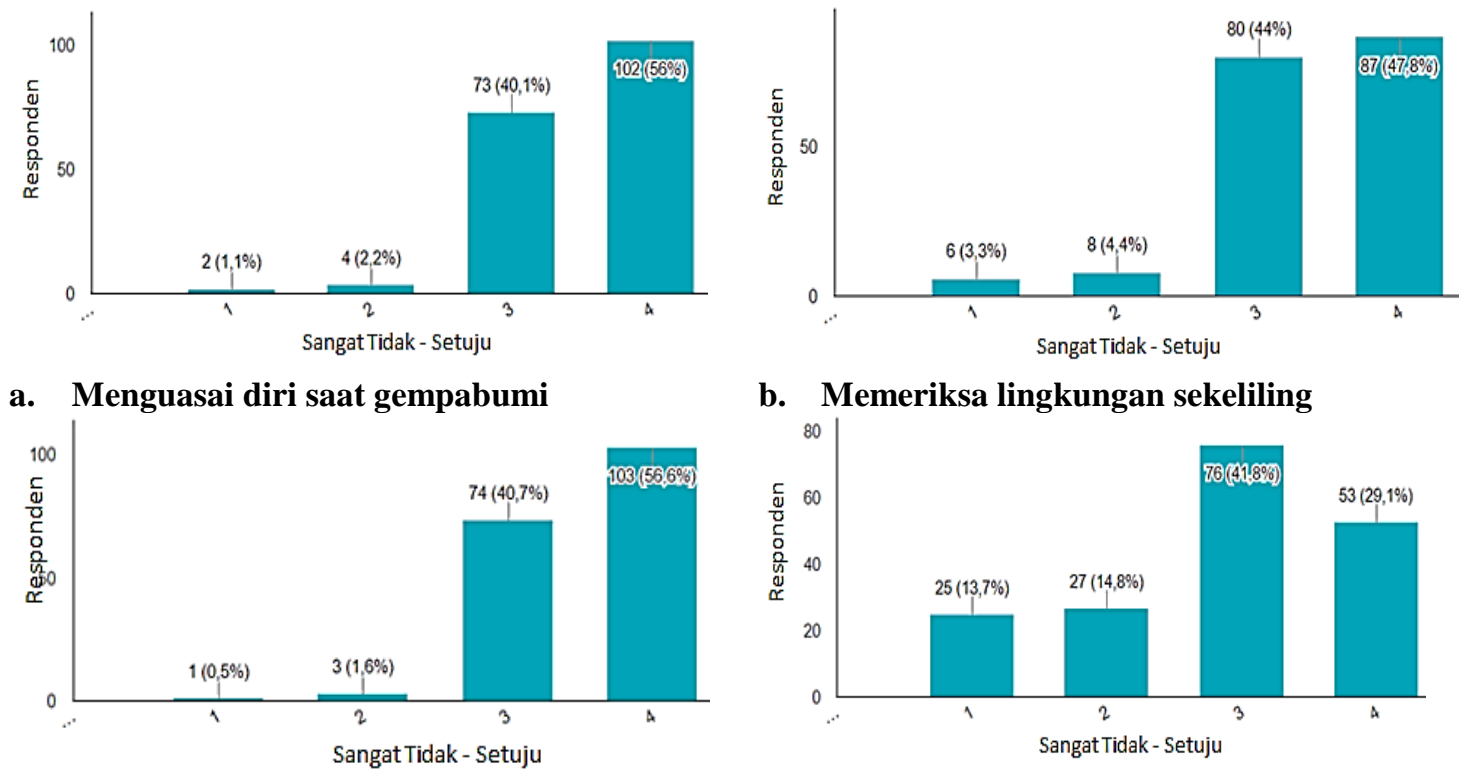

c. Bangunan yang perlu dihindari

d. Mencari informasi tentang gempabumi

Gambar 4.Grafik Hasil Analisis Deskriptif Persentase Variabel Tindakan 

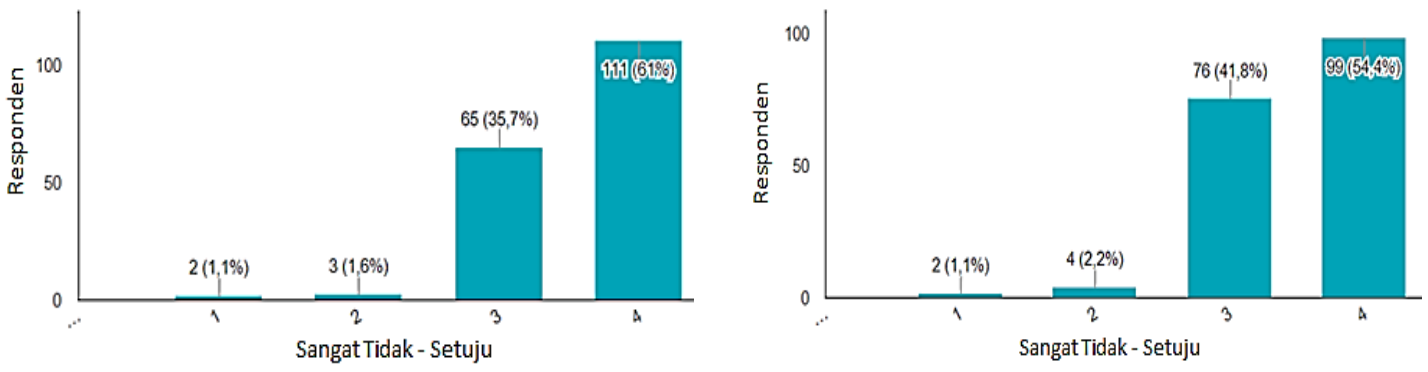

e. Jika masih berada dalam gedung

f. Kesiapsiagaan mengurangi resiko
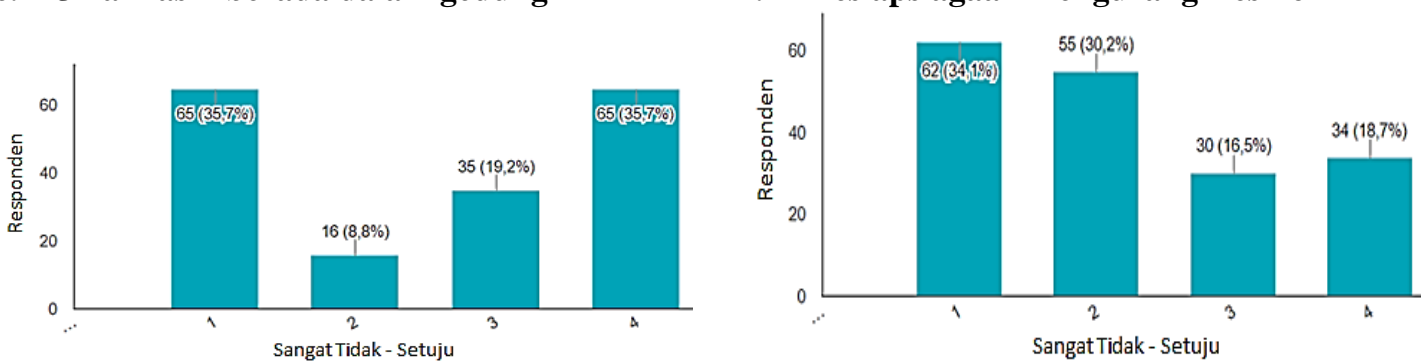

g. Berlindung pada gedung yang berpotensi tidak roboh

h. Lari keluar gedung menyelamatkan diri dari bencana

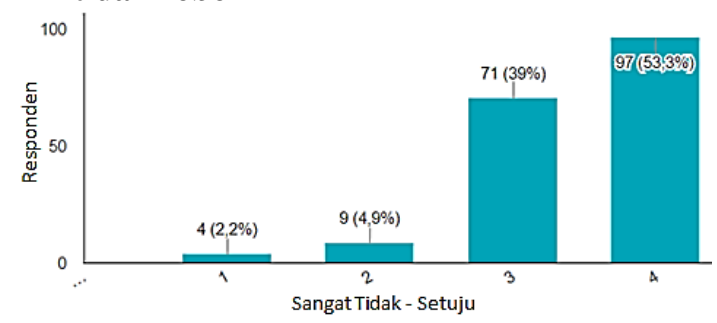

i. Memperhatikan tempat berdiri

Gambar 4.Grafik Hasil Analisis Deskriptif Persentase Variabel Tindakan (lanjutan)

Banyak tindakan yang harus dilakukan saat terjadi bencana gempabumi.Berdasarkan hasil kuesioner variabel tindakan, responden sebagai pengguna gedung mengetahui tindakan-tindakan yang tepat dilakukan saat terjadi gempabumi.Kejadian gempabumi tidak dapat diprediksi oleh karena itu tindakan cepat, tepat dan tertib merupakan pilihan tindakan terbaik.

\subsection{Analisis Variabel Kesiapsiagaan Bangunan}

Kesiapsiagaan terhadap bencana mengurangi kerugian akibat yang ditimbulkan.Meskipun dalam lingkup kecil, kesiapsiagaan masing-masing individu membantu departemen pemerintah seperti BNPB dalam melakukan sosialisasi kesiapsiagaan pada seluruh rakyat Indonesia.Kesiapsiagaan merupakan tanggungjawab pemerintah daerah serta dilaksanakan bersama-sama masyarakat dan lembaga usaha. 
Variabel kesiapsiagaan bangunan pada kuesioner memaparkan kesiapsiagaan Gedung Pendidikan terhadap bencana gempa.Hasil kuesioner variabel kesiapsiagaan dapat dilihat pada gambar 5.Gambar 5 meliputi seluruh hasil kuesioner variabel kesiapsiagaan digambarkan dalam bentuk gambar grafik.Hasil kuesioner variabel kesiapsiagaan dipengaruhi oleh pengetahuan responden mengenai bangunan siaga bencana gempa dan tindakan yang dilakukan menghadapi kejadian bencana gempa.

Gambar 5.b "Pihak pengguna gedung mengenali lokasi bangunan terhadap siaga bencana" dengan persentase sebesar $75,8 \%$ responden menyatakan bahwa pihak pengguna gedung mengenali lokasi keberadaan bangunan sehingga 82,4\% responden menyatakan bahwa Gedung dibangun sesuai dengan Standar Nasional Indonesia (SNI) dapat dilihat gambar 5mengenai pernyataan "Gedung didirikan sesuai SNI", "Siap-siaga senter, P3K, makanan, dsb", "Pelatihan menghadapi bencana", "Memberikan pembinaan menghadapi bencana gempabumi", dan mengenai "Kebijakan dan panduan penanganan gawat darurat bencana gempabumi" memperlihatkan hampir $60 \%$ responden tidak setuju bahwa pihak pengelola Gedung telah melakukan pemberian pengetahuan, pembinaan dan pelatihan/ simulasi bencana gempabumi. Menurut PERDA 2010, Pembinaan, pelatihan dan simulasi dapat diselenggarakan oleh siapapun berdasarkan tujuan pencapaian kesiapsiagaan individu menghadapi bencana.

Pada ummnya responden tidak mengetahui sistem dan tidak memantau sistem peringatan dini bencana gempabumi,responden hasil kuesioner dapat dilihat padagambar 5 mengenai "Memantau sistem peringatan dini bencana gempabumi", dan "Tertera keterangan mengenai bencana dan kesiapsiagaan yang mudah ditemukan pada Gedung". Menurut Undang-undang Republik Indonesia Nomor 24 Tahun 2007 mengenai Penanggulangan Bencana.Peringatan dini adalah serangkaian kegiatan pemberian peringatan sesegera mungkin kepada masyarakat tentang kemungkinan terjadinya bencana pada suatu tempat oleh lembaga yang berwenang.Peringatan dini terhadap Gedung Pendidikan sangat menolong seluruh pengguna gedung untuk bertindak lebih awal sebelum akibat lebih parah yang ditimbulkan oleh bencana gempabumi.Maka sekalipun gempabumi menyebabkan gedung hancur volume korban jiwa berkurang. 

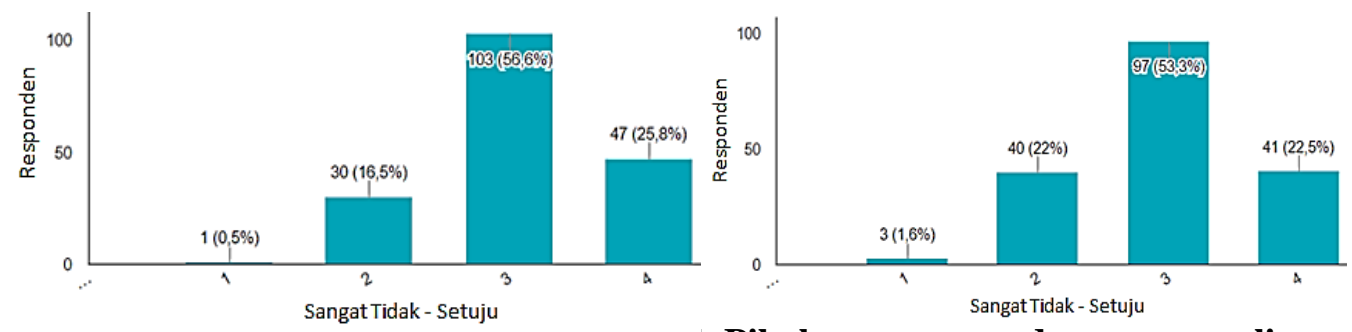

a. Gedung didirikan sesuai SNI

b.Pihak penggunagedungmengenali lokasibangunan terhadap siaga bencana
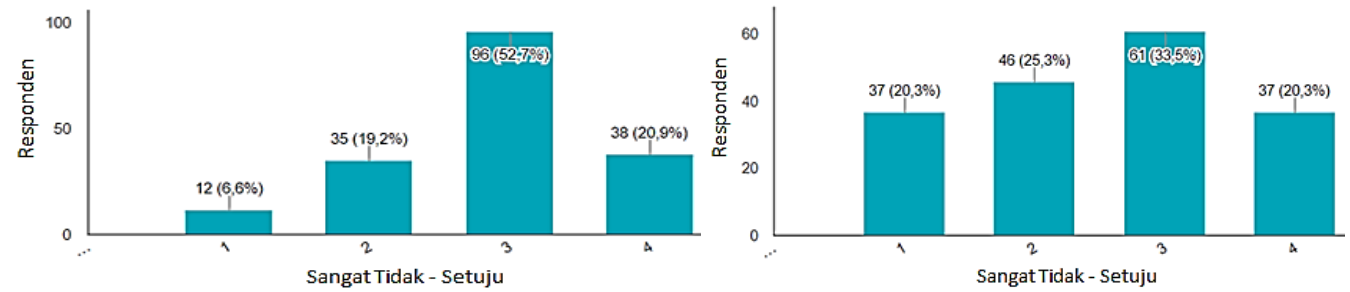

c. Penempatan perabotan dengan tepat

d. Catatan nomor telepon penting
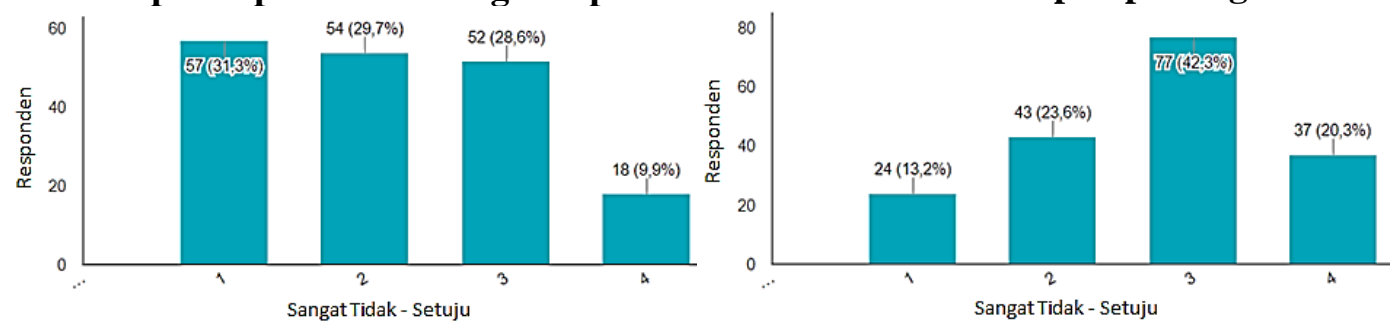

e. Simulasi siaga bencana gempabumi

f. Siap-siaga senter, P3K, makanan, dsb.
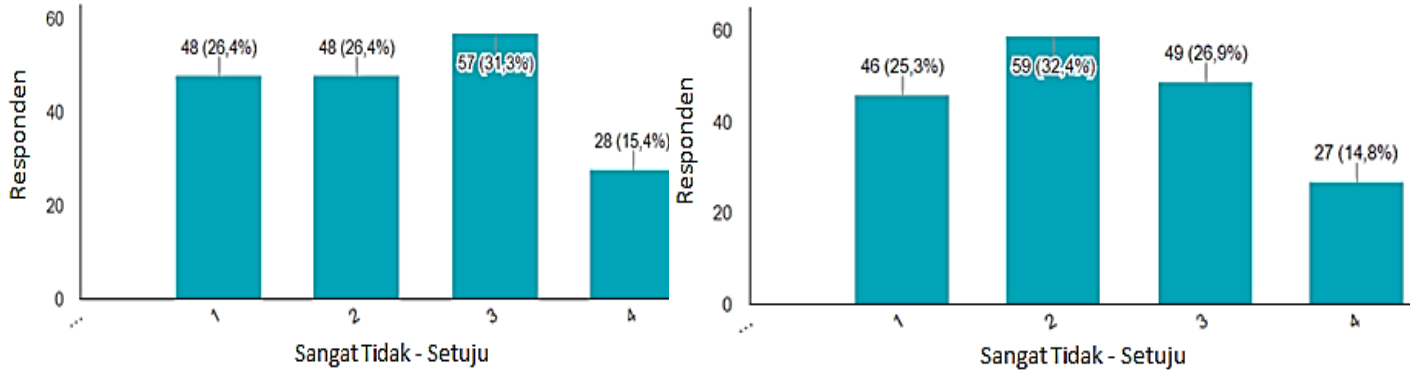

g. Pelatihan menghadapi bencana

h. Memberikanpembinaanmenghadapiben canagempabumi
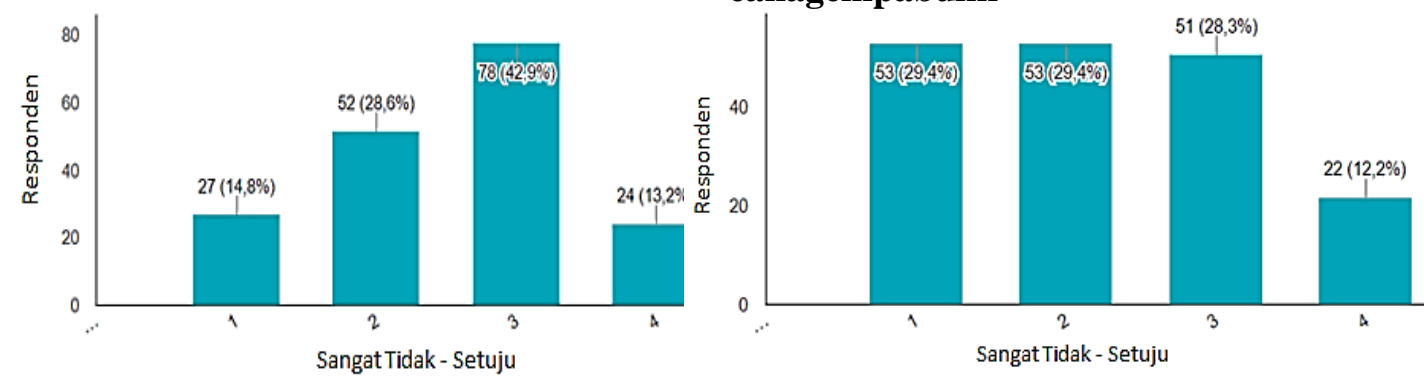

i.

Kebijakan

dan j. Memberikan panduanpenanganangawatdaruratb encanagempabumi siagaan

Gambar 5 Grafik Hasil Analisis Deskriptif Persentase Variabel Kesiapsiagaan 

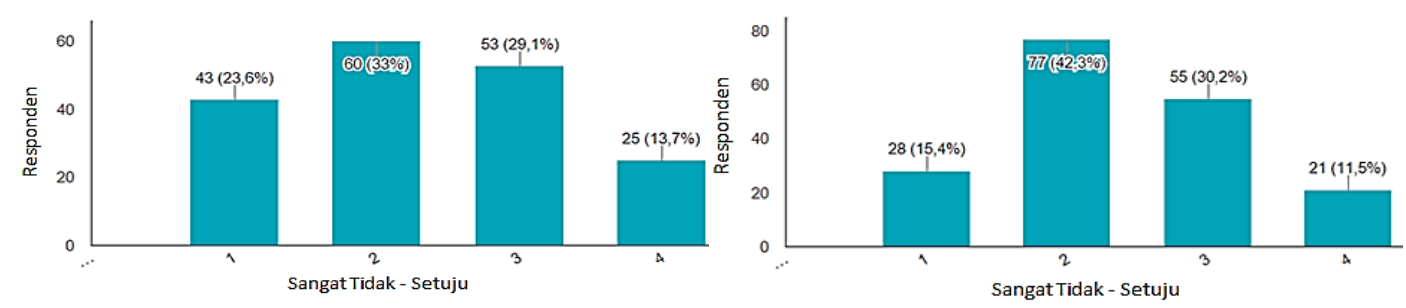

k. Rencana tanggap darurat bencana

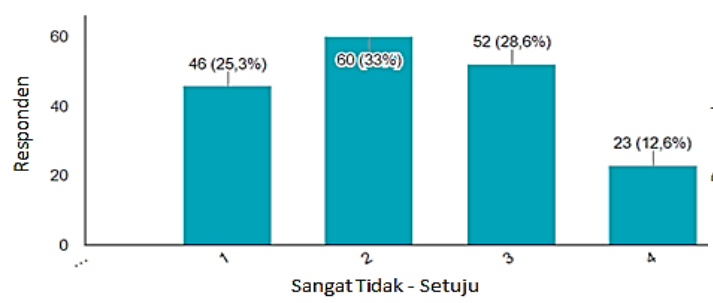

1. Memantau system peringatan dini bencaan gempa bumi

m. Tertera keterangan mengenai bencana dan kesiapsiagaan yang mudah ditemukan pada Gedung

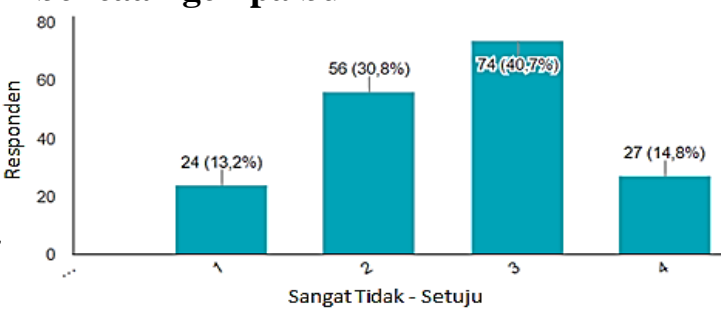

n.

Mengetahui system peringatanbencanagempabumi

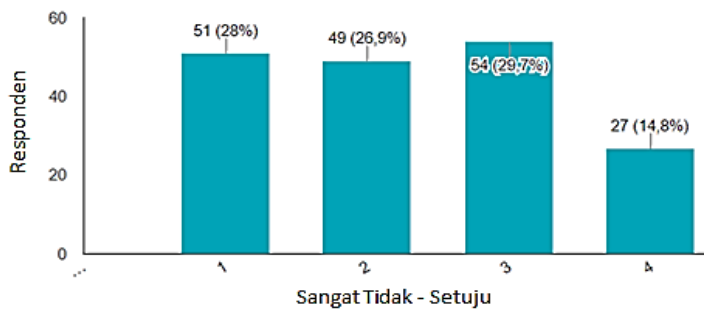

o. Jalurrambuevakuasilengkap di pasang pada Gedung

Gambar 5 Grafik Hasil Analisis Deskriptif Persentase Variabel Kesiapsiagaan (Lanjutan)

Kesiapsiagaan bencana gempabumi berarti memiliki pengetahuan dan mengetahui tindakan menghadapi bencana gempabumi. Responden memiliki pengetahuan dan mengetahui tindakan menghadapi bencana gempabumi, tetapi Gedung Pendidikan belum memenuhi bangunan siaga bencana gempa. Responden merasa bahwa bencana gempabumi adalah hal yang harus diwapadai sehingga bangunan siaga bencana gempa perlu diwujudkan, agar terbangun kesiapsiagaan terhadap bencana gempabumi dan dapat mengurangi risiko yang ditimbulkan.

\subsection{Tips Menghadapi Bencana Gempabumi}

Berikut ini adalah tips yang dapat dilakukan jika terjadi gempabumi (KOGAMI, 2007):

1. Merunduk, lindungi kepala dan bertahan di tempat aman.

2. Beranjak beberapa langkah menuju tempat aman terdekat.

3. Tetap di dalam ruangan sampai guncangan berakhir dan anda yakin telah aman untuk keluar. 
4. Menjauh dari jendela.

5. Lindungi kepala dari barang yang dapat runtuh.

6. Cari titik aman yang jauh dari kemungkinan rubuhnya, pohon, dan kabel.

7. Rapatkan badan anda ketanah.

8. Beritahu kepada seluruh keluarga dan masyarakat. Umumkan lewat pengeras suara di tempat ibadah.

9. Periksa diri anda, apakah ada yang terluka.

10. Lindungi diri anda dari bahaya selanjutnya.

11. Menolong orang lain yang terluka.

12. Memberikan pertolongan pertama terhadap korban sedera serius.

13. Jika terjadi kebakaran, cari pemadam api.

14. Matikan gas jika anda mencium bau gas atau jika menurut anda gas tersebut mengalami kebocoran.

15. Hidupkan radio atau media masa lain yang dapat memberikan intruksi dan informasi.

Kesiapsiagaan bangunan terhadap becana gempabumi dipengaruhi oleh pengetahuan berdasarkan informasi yang diperoleh.

\section{Simpulan dan Saran}

\subsection{Simpulan}

Sebuah rambu jalur evakuasi telah dipasang di lantai 4 Gedung Pendidikan, hanya saja jumlah ini relatif kurang informatif, mengingatjumlahpopulasi yang cukuptinggidaribangunangedungtersebut. Sebagian pintumenujujalurpotensialevakuasi pada Gedung Pendidikan selalu terkunci tanpa alasan jelas. Observasimenghasilkanjalur rambu evakuasi pada Gedung Pendidikan belummemadai.

Berdasarkan hasil kuesioner dan wawancara, pengguna dan pemangku kepentingan di Gedung Pendidikan memiliki pengetahuan mengenai siaga bencana gempabumi. Pengguna dan pemangku di Gedung Pendidikan mengetahui tindakan yang perlu dilakukan dalam menghadapi bencana gempabumi, akan tetapi belum ada kebijakan secara langsung dan sosialisasi kesiapsiagaan bangunan terhadap bencana gempa secara terpadu. Simpulan salah satu Gedung Pendidikan di Bandung bukan termasuk Gedung yang siapsiaga terhadap bencana gempa.

\subsection{Saran}

Saran yang dapat disampaikan untuk penelitian lebih lanjut adalah antara lain untuk melakukan penelitian evaluasi bangunan siaga bencana gempa terhadap seluruh bangunan Gedung Pendidikan, secara khusus di Bandung. Agar tercipta kesiapsiagaan 
gedung sebagai tempat kegiatan pelaksanaan pendidikan dan terwujud para pengguna gedung yang siap menghadapi bencana gempa.

\section{DAFTAR PUSTAKA}

1. Afiyan. (2013, Januari 31). Jalur Evakuasi Tepat, Semua Orang Selamat, Bagian 2 (Tamat). Retrieved Januari 2, 2016, from Lorco: http://www.lorco.co.id

2. Badan Pengembangan dan Pembinaan Bahasa. (n.d.). Retrieved Oktober 8, 2015, from Kamus Besar Bahasa Indonesia Web Site: http://kbbi.web.id/

3. BMKG. (2011). Sosialisasi Mitigasi Gempa Bumi Pada Gedung Bertingkat Di Kota Bandung.

4. BMKG. (2015). Badan Meteorologi, Klimatologi, dan Geofisika. Retrieved from http://inatews.bmkg.go.id/new/glossary.php

5. BMKG. (2015). Badan Meteorologi, Klimatologi, dan Geofisika. Retrieved from http://inatews.bmkg.go.id/new/gempa_dirasakan.php

6. BNPB. (2011, Oktober). Jurnal Penanggulangan Bencana. Jurnal Penanggulangan Bencana.

7. BNPB. (2012). Pedoman Penerapan Sekolah/Madrasah Aman Dari Bencana.

8. Cindrawaty,L.,\&Nurul,P.(2015). Kesiapsiagaan Komunitas Sekolah Dalam Menghadapi Bencana Di Kabupaten Magelang. Jurnal Teknik Sipil, 1-75

9. Djohanputro, B. (2013, May 21). PPM Manajemen. Retrieved 2015, from Wordpress: https://manajemenppm.wordpress.com/2013/05/21/manajemen-bencanadisaster-management/

10. Edwin Syalli Siregar, Y. A. (2015). Jurnal Online ITENAS. Usulan Perancangan Jalur Evakuasi Menggunakan Algoritma Djikstra.

11. Ella Yulaelawati, P., \& Usman Syihab, P. (2008). Mencerdasi Bencana: banjir, tanah longsor, tsunami, gempa bumi, gunung api, kebakaran. Jakarta: Grasindo.

12. Gubernur. (2007). Patent No. 5. Sumatra Barat.

13. Husein, R. (2009). Jalur Evakuasi Gempa Dilupakan.

14. Husein, R. (2013). Siaga Darurat Bencana.

15. Nurchayat, N. A. (2014). Skripsi. In Perbedaan Kesiapsiagaan Menghadapi Bencana Gempa Bumi Antara Kelompok Siswa Sekolah Dasar yang Dikelola dengan Strategi Pedagogi dan Andragogi. Yogyakarta: Universitas Negeri Yogyakarta.

16. PERDA. (2007). Peraturan Daerah Provinsi Sumatera Barat.

17. PERDA. (2010). Peraturan Daerah Provinsi Jawa Barat Nomor 2 Tahun 2010 Tentang Penyelenggaraan Penanggulangan Bencana. 
18. PERDA. (2013). Peraturan Daerah Kabupaten Bandung Nomor 2 Tahun 2013 Tentang Perda Penyelenggaraan Penanggulangan Bencana Di Kabupaten Bandung.

19. Permana, H., Carolita, I., \& Rasyid, M. (2007). Pedoman Pembuatan Peta Jalur Evakuasi Bencana Tsunami. Jakarta: Kementrian Negara Riset dan Teknologi.

20. Prof. Ir. Sukandarrumidi, M. P. (2010). Bencana Alam \& Bencana Anthropogene. Yogyakarta: Kanisius.

21. Rachmat, A. (2015). Partisipasi Masyarakat Dalam Mitigasi.

22. UNDANG-UNDANG. (2007). UNDANG-UNDANG REPUBLIK INDONESIA NOMOR 24 TAHUN 2007 TENTANG PENANGGULANGAN BENCANA. Jakarta.

23. UNDANG-UNDANG. (2008). UNDANG-UNDANG REPUBLIK INDONESIA NOMOR 8 TAHUN 2008 TENTANG BADAN NASIONAL PENANGGULANGAN BENCANA. Jakarta.

24. UNESCO. (2007). Kajian Kesiapsiagaan Masyarakat dalam Mengantisipasi Bencana Gempa Bumi dan Tsunami di Nias Selatan. Jakarta: UNESCO.

25. UNESCO. (2015). www.sigana.web.id. Retrieved from www.sigana.web.id: http://www.sigana.web.id/index.php/gempa-bumi.html

26. Vision, World. (2011). Sekolahku Siaga Bencana. Padang: World Vision.

27. Yulianto, F. (2011). Management Bencana Di Indonesia.

28. Yulianto, F. (2015). Management Bencana Di Indonesia. Siklus Disaster Management atau Disaster Management. 